\title{
Top Management Capabilities and Firm Efficiency: Relationship via Resources Acquisition
}

\author{
Muhammad Sualeh Khattak ${ }^{1}$, Syed Zulfiqar Ali Shah ${ }^{2}$
}

\begin{abstract}
Considering the deficiency of resources in SMEs, a number of studies have been shown interest in the determinants of external resources acquisition but the results are fragmented. Particularly, the role of Top Management Capabilities (TMC) in resource acquisition and efficiency in the SME sector has been neglected. This study discusses the role of TMC-being intangible resources in SMEs' efficiency with a mediating role of resource acquisition. This research is quantitative in nature and collected cross-sectional data through a structured questionnaire from 311 owners and managers of Pakistani SMEs. After analyzing the model using AMOS, the results indicate that TMC significantly facilitate firms in resource acquisition and enhance their efficiency; however, resource acquisition partially mediates the relationship between TMC and SMEs efficiency. This research recommends that SMEs should focus on TMC (instead of blindly investing money in other strategies) in order to acquire valuable tangible and intangible resources that are necessary for long term survival and efficiency. Further implications are discussed for owners, managers and practitioners.
\end{abstract}

Keywords: Top management capabilities, Resources acquisition, SMEs, firm efficiency

\section{Introduction}

One of the major reasons of SMEs failure is "lack of resources". Therefore, acquiring valuable resources has become a major focus of SMEs in both the developed and under-developed economies. Scholarly interest has diverted from studying the characteristics of firms' resources as a source of competitive advantage to understanding the managerial capabilities through which firms acquire, manage, configure, orchestrate, and transform their resources (Huy \& Zott, 2019; Ying, Hassan \& Ahmad, 2019). Although, adequate resources are essential but insufficient to achieve a competitive advantage, which requires the top managers to acquire and efficiently manage the requisite resources (Sirmon \& Hitt, 2003). As argued by the Upper Echelon Theory

1 PhD Scholar at International Islamic University Islamabad Pakistan. Email: sualeh_ktk@yahoo.com

2 Associate Professor, Faculty of Management Sciences, International Islamic University Islamabad Pakistan. Email.zulfiqar.shah@gmail.com

\section{ARTICLE HISTORY}

01 Jan, 2019 Submission Received

13 Mar, 2019 First Review

09 May, 2019 Second Review 17 Jan, 2020 Third Review

13 Feb, 2020 Accepted 
(originally presented by Hambrick \& Mason, 1984), organizations' outcomes and success depend on TMC and competencies (Hambrick \& Mason, 1984). For last several decades, a number of studies have discussed the role of top management in organizations' outcomes and performance in developed and emerging economies (Anwar, Khan \& Khan, 2018a; Dezsö \& Ross, 2012; Haleblian \& Finkelstein, 1993; Smith, Smith \& Verner, 2006) and have discussed a variety factors that influence SMEs innovative activities and performance (e.g. Gul \& Nouman, 2009; Nouman, Taj \& Gul, 2017). More precisely, one stream of literature discussed and emphasized on the direct influence of TMC on firm's performance (Dezsö \& Ross, 2012; Nadolska \& Barkema, 2014; Nielsen \& Nielsen, 2013) while the other stream believed in indirect influence and claims that the relationship between TMC and performance can be mediated by other relevant factors such as dynamic capabilities (Hermano \& Martín-Cruz, 2016), operational activities (Gudergan \& Wilden, 2018), knowledge sharing (García-Sánchez, García-Morales \& Bolívar-Ramos, 2017) and human resources (Collins \& Clark, 2003). However, it is yet to be explored either TMC directly influence firms' efficiency or resources acquisition plays any role to fully comprehend the link. We, therefore, seek a requisite gap in the literature of Upper Echelon Theory to examine the role of TMC on firm performance with a mediating role of resource acquisition.

It is inevitable for businesses to gain the requisite resources for the smooth operation of the allied activities necessary for running the businesses, particularly in this hyper-turbulent business environment. For instance, in emerging economies such as Pakistan, around half of the SMEs fail in the initial stages of the business cycle, just because of lack of resources, capabilities and support (Shah, Gul \& Aziz, 2011). In China, $67 \%$ of ventures fail in their infancy while an overall $85 \%$ of ventures fail within the first 10 years of their operations (Parnell, Long \& Lester, 2015). The situation is no different even in the developed economies, for example in the USA, the failure ratio of SMEs is on the peak that every year in the USA, around 700,000 ventures are initiated out of which only $10 \%$ become successful (Sambasivan, Abdul $\&$ Yusop, 2009). One of the major reasons for these debacles is attributed to the lack of requisite resources (Anwar, Rehman \& Shah, 2018b; Jiang, Liu, Fey \& Jiang, 2018). This high failure ratio warrants the identification of the specific factors which could facilitate the SMEs in acquiring resources to avoid their debacles, particularly in their infancy. Surprisingly, these failures are more prominent in the developed economies, where these small industries are incubated by the government through various platforms. The incubation services are for their initial stages, however, the long term survival and competitiveness largely depend on the acquisition capabilities of these SMEs to acquire their requisite resources from their external environment. Apparently, the inabilities of these SMEs in acquiring adequate external resources 
are attributed to the high cost, time-consuming and lack of internal capabilities (Ying et al., 2019). SMEs do not receive satisfactory support from government and institutions, particularly in the developing economies (Songling, Ishtiaq, Anwar \& Ahmed, 2018), therefore the only source of their resources is their external environment which is shared by all other competitors, and only the managers' capabilities can win them their resources. Therefore, drawing on the UET theory (Hambrick \& Mason, 1984) and Resourced Based View (Barney, 1991), this research is conducted to examine the role of TMC - being an intangible and less expensive resource - to enable the firms to acquire external resources to enhance their efficiency. There is no universal definition of SMEs across the globe. These discrepancies are attributed to the underlying dimensions which are used to define the SME. For example, it is often defined on the basis of three major dimensions; a number of employees, total assets and an annual turnover (Anwar et al., 2018a; Dar, Ahmed \& Raziq, 2017). Some important definitions of SMEs across the globe are provided and compared in Table 1. However, in the context of Pakistan, the Small and Medium Enterprise Development Authority (SMEDA) defined SMEs based on the above three criteria, such as those ventures which have less than 250 employees, paid-up capital up to Rs. 25 million and annual sales up to Rs. 250 million (Dar et al., 2017). This definition is comparable to the definitions used by other authorities across the globe as mentioned in Table-1, therefore, we relied on the definition of the SMEDA for selection of the sample of this study. In addition, the operationalization of other variables of the study is provided in the Table-2, below.

This research aims to contribute to the upper echelon and RBV theories by examining the indirect relationship between TMC and firms' efficiency through the mediating role of resource acquisition. First, SMEs in emerging economies are unable to invest a huge amount in big projects because of a lack of financial capabilities (Kapetaniou \& Lee, 2018), which forces them to go for cheap resources which are often insufficient for their operations (Anwar, 2018). In such situations, it is argued that the top management's capabilities to gain the requisite effective and efficient resources for the businesses may enhance the survival of their businesses. Second, in general, senior managers of SMEs cannot acquire a sustainable competitive position in a turbulent due if they face resource constraints. For instance, the Resource Base View (RBV) theory suggests that unique, rare and inimitable resources enable a firm to gain a sustainable competitive position and superior performance in dynamic markets (Barney, 1991). This research assesses the importance of TMC that has recently been discussed in the context of RBV theory by Badrinarayanan, Ramachandran and Madhavaram (2019). Similarly, Upper Echelon Theory also identified the top managers' abilities as one of the important factors in a firm's sustainability and competitiveness (Hambrick \& Mason, 1984) but research is scant about the role of TMC in acquiring 
external resources in the context of the RBV and Upper Echelon theories. Third, in a highly competitive environment, small firms rely on their internal capabilities (e.g. management capabilities) to respond to external changes (Yang, Ishtiaq \& Anwar, 2018). This study implicates that the top managers of emerging SMEs are the focal points to acquire external resources in the competitive market where the resources are scarce. For instance, Eesley, Hsu and Roberts (2014) argued that TMC can spur a new venture performance in a competitive environment. The top management support is not only essential for high performance but also helpful for innovation in an organization (Heyden, Sidhu \& Volberda, 2018). We aim that the TMC help in acquiring external tangible and intangible resources that can be considered very crucial for their firms' efficiency.

Table 1: Definitions of SMEs in different Countries

\begin{tabular}{|c|c|c|}
\hline Country & Industry types & Definitions of SMEs \\
\hline Canada & SME & $\begin{array}{l}\text { Independent firms having less } \\
\text { than } 200 \text { employees q }\end{array}$ \\
\hline France & SME & $<500$ employees \\
\hline Germany & SME & $<100$ employees \\
\hline Hong Kong & Manufacturing & $<50$ employees \\
\hline Indonesia & SME & $<100$ employees \\
\hline Ireland & SME & $<500$ employees \\
\hline Italy & Small enterprises & $<200$ employees \\
\hline \multirow[t]{3}{*}{ Japan } & $\begin{array}{l}\text { Manufacturing, mining and } \\
\text { transportation }\end{array}$ & $\begin{array}{l}<300 \text { employees or invested } \\
\text { capital less than } 10 \text { million yen }\end{array}$ \\
\hline & Construction & $\begin{array}{l}<100 \text { employees or capitaliza- } \\
\text { tion less than } 30 \text { million yen }\end{array}$ \\
\hline & $\begin{array}{c}\text { Whole sale trade, Retail trade } \\
\text { and services }\end{array}$ & $\begin{array}{l}<50 \text { employees or capitaliza- } \\
\text { tion less than } 10 \text { million }\end{array}$ \\
\hline \multirow[t]{2}{*}{ Korea } & Manufacturing & < 300 employees \\
\hline & Mining \& transportation & $<300$ employees construction \\
\hline \multirow[t]{3}{*}{ Malaysia } & SMIs & $\begin{array}{l}<75 \text { full time workers or with a } \\
\text { shareholder fund of < RM } 2.5 \\
\text { million (US } \$ 1 \text { million) }\end{array}$ \\
\hline & SIS & $\begin{array}{l}\text { Manufacturing establishments } \\
\text { employing between } 5 \text { and } 50\end{array}$ \\
\hline & MIS & $\begin{array}{l}\text { employees or with a sharehold- } \\
\text { ers fund up to RM } 500,000\end{array}$ \\
\hline
\end{tabular}




\begin{tabular}{|c|c|c|}
\hline & & Manufacturing establishments \\
\hline \multirow[t]{2}{*}{ Netherlands } & Small enterprises & $<10$ employees \\
\hline & Medium enterprises & 10-100 employees \\
\hline Philippines & Small enterprises & $\begin{array}{c}<200 \text { employees, revenue }<\mathrm{P} \\
40 \text { million }\end{array}$ \\
\hline \multirow[t]{3}{*}{ Singapore } & Manufacturing & Fixed assets $<\mathrm{S} \$ 15$ million \\
\hline & Services & $\begin{array}{c}<200 \text { employees and fixed } \\
\text { assets }\end{array}$ \\
\hline & & $<\mathrm{S} \$ 15$ million \\
\hline \multirow[t]{2}{*}{ Spain } & Small enterprises & $<200$ employees \\
\hline & Medium enterprises & $<500$ employees \\
\hline \multirow[t]{2}{*}{ Sweden } & SME & Autonomous firms with \\
\hline & & $<200$ employees \\
\hline Switzerland & SME & No fixed definition \\
\hline \multirow[t]{3}{*}{ Taiwan } & $\begin{array}{l}\text { Manufacturing, mining and } \\
\text { construction industries }\end{array}$ & $\begin{array}{c}<\text { NT\$60 million of sale vol- } \\
\text { ume and < } 200 \text { employees }\end{array}$ \\
\hline & Service industries & $\begin{array}{c}<\mathrm{NT} \$ 80 \text { million of sale } \\
\text { volume }\end{array}$ \\
\hline & & $<50$ employees \\
\hline \multirow[t]{2}{*}{ Thailand } & Labour intensive sector & $<200$ employees \\
\hline & Capital intensive sectors & $<100$ employees \\
\hline United Kingdom & SME & No fixed definition \\
\hline \multirow[t]{3}{*}{ United States } & Very small enterprises & $<20$ employees \\
\hline & Small enterprises & 20-99 employees \\
\hline & Medium enterprises & 100- 499 employees \\
\hline \multirow[t]{2}{*}{ Vietnam } & SME & No fixed definition, generally \\
\hline & & $<200$ employees \\
\hline
\end{tabular}

Table 2: Operationalization of the Variables

\begin{tabular}{|c|c|c|}
\hline Variable & Operationalization & Source \\
\hline $\begin{array}{c}\text { Top Manage- } \\
\text { ment Capabil- } \\
\text { ities }\end{array}$ & $\begin{array}{c}\text { "the capabilities with which managers build, inte- } \\
\text { grate, and reconfigure organizational resources and } \\
\text { competences" (p. 1012) }\end{array}$ & $\begin{array}{c}\text { Adner and Helfat } \\
\text { (2003) }\end{array}$ \\
\hline
\end{tabular}




\begin{tabular}{|c|c|c|}
\hline $\begin{array}{c}\text { Resource Acqui- } \\
\text { sition }\end{array}$ & $\begin{array}{c}\text { Firm's ability to capitalize on its network and ability } \\
\text { to acquire external tangible and intangible resources } \\
\text { such as technological, financial, managerial, infor- } \\
\text { mational and human resources etc. }\end{array}$ & $\begin{array}{c}\text { Jiang et al., 2018; Ying } \\
\text { et al., (2019). }\end{array}$ \\
\hline Efficiency & $\begin{array}{c}\text { Output to input ratio: in terms of profitability, } \\
\text { return on investment and return on assets etc. OR } \\
\text { producing/earning more with the least of resources. }\end{array}$ & Martin and Javalgi, 2016 \\
\hline
\end{tabular}

Sources: Adner and Helfat (2003); Jiang et al., (2018); Ying et al., (2019); and Martin and Javalgi (2016)

\section{Theoretical Background}

The present study unleashes the importance of TMC in the acquisition of resources that can spur SMEs' efficiency. The model is based on two major theories; UET and the RBVT. For instance, UET sheds light on top managers' background and psychological features that can influence organizations' performance (Hambrick $\&$ Mason, 1984). In the present study, we emphasize on demographics factors while parsimoniously skip the psychological factors of top managers due to little importance in our model. To put the claim of UET into detail, the demographic characteristics such as age, education, experience and competencies of top managers affect their business performance (Hambrick \& Mason, 1984; Anwar, Shah \& Khan 2018c). Managerial competencies enable them to seize new opportunities, get information about customers and markets, build a network and acquire necessary resources that result in high profitability (Gillis, Combs \& Yin, 2018; Koryak et al., 2015). Because lack of competences hinder venture growth and results in a low performance (Kapetaniou \& Lee, 2018). Therefore, SMEs need intellectual, capable, competent and skilled staff to make effective strategic decisions. In a similar debate, the RBVT states the worth of tangible and intangible resources in the competitiveness and performance of a business (Barney, 1991). Some studies give more weight to tangible resources (Kim, Shin \& Min, 2016; Schriber \& Löwstedt, 2015) while others rely on intangible resources (Anwar et al., 2018a; Bharadwaj, Chauhan \& Raman 2015; Huy $\&$ Zott, 2019). Indeed both are necessary for a long term survival-and hereby used in this research. The theory further demonstrates that an enterprise with sufficient resources; rare, unique and immutable delights a superior position in the dynamic market. A common problem reported in SMEs is lack of resources, hence acquiring external resources becomes a key effort to boost operational activities (Anwar et al., 2018b). However, it is not easy to acquire external resources, enterprises must-have capabilities and skilled managers to make it happen (Ying et al., 2019). Therefore, it is crucial to assess how SMEs get efficiency through TMC and resources. 


\section{Hypotheses Development}

\subsection{Top management capabilities and firm's efficiency}

The top management team is the central factor that significantly influences a firm's efficiency (Pegels \& Yang, 2000). TMC are the firm-level indicators that affect a firm's performance (Bathula \& Singh, 2015). TMC are not only important for the high performance of a firm but also influence innovative and operational activities (Salehi, DashtBayaz, \& Moghadam, 2018). Upper Echelon theory suggests that a firm's success and performance are influenced by the top management team rather than bottom or middle-level managers (Hambrick \& Mason, 1984; Tseng \& Lee, 2014). The former, begin the strategic decision-makers, must have the capability to recognize and seize any new opportunity arising out of the external environment that is essential for high profitability and sustainability (Adner \& Helfat, 2003; Helfat \& Martin, 2015). Not only the managerial skills but also the intellectual capabilities of the top management influence the embeddedness of resources' fusion among firms (Laud, Karpen, Mulye \& Rahman, 2015; Díaz-Fernández, Gonzalez-Rodríguez, \& Simonetti, 2015). Hence, for procurement of opportune resources, firms improve their external capabilities and internal social capital (Du, Guariglia \& Newman, 2015), especially in the emerging markets, where senior managers are relatively more autonomous to use different sources such as networking and social capital to configure their firm performance by winning the requisite resources (Kotabe, Jiang \& Murray, 2017). Top management involves themselves in multidimensional activities such as project planning, budgeting and evaluation which are helpful for effective business operations (Hermano \& Martín-Cruz, 2016). For instance, more intellectual top managers can seize the best position in the market as compared to less intelligent managers (Díaz-Fernández et al., 2015). Senior management involvement is necessary for firm performance because they not only take part in the strategic level decision making but also active in the operational level decision making and operations of their business (Hermano \& Martín-Cruz, 2016). Therefore, we hypothesize the first hypothesis as:

$\mathrm{H}_{1}$ : Top management capabilities have a significant positive influence on firms' efficiency in the SMEs of Pakistan

\subsection{Top management capabilities and resources acquisition}

The important characteristics of the managers, which overshadowed all other attributes of the managers when it comes to the top management are their personality traits (Peterson, Smith, Martorana \& Owens, 2003). Some of the attributes are inevitable for a good manager to lead his team and run the business both efficiently and effectively. For example, in terms of personality, not all managers actively par- 
ticipate in organizational change and activities, due to their introvert nature. While, the extrovert and managers exhibiting high scores on the openness are more inclined towards the change process and are capable of persuading the followers to adopt the change (Anwar et al., 2018c; Peterson et al., 2003). More precisely, the more persuading nature of a manager would help him win the important and inevitable resources for the firm over his competitors (Helfat \& Martin, 2015). The top management team establishes different types of a network with external bodies in order to gain useful resources which are necessary for the efficient performance of the firm (Kauppila, 2015; Sirmon \& Hitt, 2003).

In the context of the emerging economies such as Pakistan, in the absence of any institutional support from the government, SMEs face severe resource constraints. In such situations, top managers' idiosyncratic capabilities such as business experience, financial literacy and intellectual capital facilitate them in acquiring external tangible and intangible resources (Ying, Hassan \& Ahmad, 2019). Especially in the initial stages of their operations, they need financial capital for operational activities. Hence, managerial capabilities such as human capital, skills, education and experience assist them in acquiring external financial resources (Ko \& McKelvie, 2018). Some managers acquire external resources very proactively which in turn boosts their firm's profitability (Helfat \& Peteraf, 2015). Top managers' skills and capabilities are significantly related to resource acquisition (Spithoven \& Teirlinck, 2015). Hence, it can be argued that competent managers are needed to acquire and manage resources in productive ways to increase efficiently utilize the available resources. Therefore, based on these assertions we hypothesize the next hypothesis as:

$\mathrm{H}_{2}$ : Top management capabilities have a significant positive influence on the acquisition of resources in the SMEs of Pakistan.

\subsection{Resources acquisition and firm's efficiency}

According to the RBV theory, a firm with unique and rare resources gain a sustainable competitive position over other firms in the hyper-turbulent market (Barney, 1991). Various resources and capabilities are needed at different levels of business operations, therefore, it is imperative for the managers involved at each level to proactively pursue their goals and make efforts to gain the requisites resources for efficient and effective performance of their assigned roles and operations (Zhang, Liu, Tan, Jiang \& Zhu, 2018). The top management requires the entrepreneurial capabilities to assess the current scenario of resources and to seek the opportunities in the external environment that are arising out of the changes in the external environmental demographics (Koryak et al., 2015). Entrepreneurs persistently struggle to acquire enough resources to make a sustainable competitive position in a dynamic market (Zott \& 
Huy, 2007). In a dynamic market, a firm with adequate resources and capabilities can gain a highly competitive status over other firms (Camisón et al., 2016). Management capabilities and entrepreneurial activities are significantly related to each other which resultantly configure the high growth of business firms (Sahimi, Rizal, Husin \& Kamarudin, 2017). Adequate resources enable firms to make effective strategies and plan for the improvement of efficiency (Ferreira \& Fernandes, 2017). Drawing on the RBV theory, sufficient resources enable firms to perform their operational activities efficiently that can stimulate their overall organizational performance (Barney \& Arikan, 2001). For instance, Jiang et al., (2018) argued that adequate resources are very crucial for the smooth running of operational activities which in turn accumulates at the organizational level to improve its financial performance. Similarly, resource acquisition has been considered very profitable for SMEs' sustainable competitive position (Pulka, Ramli, \& Bakar, 2018; Ying et al., 2019). Based on these assertions, we also argue that the acquisition of the external resources is important for the firms' performance, therefore, we state the next hypothesis as:

$\mathrm{H}_{3}$ : Resources acquisition has a significant positive influence on efficiency of the SMEs of Pakistan

\subsection{TMC, Resources acquisition and firms' efficiency}

There is no doubt that top management plays a noteworthy role in the performance of a firm, however, the links between the TMC and the firm's efficiency is not so straightforward. There are different studies that considered different black boxes for the explanation of the association between the TMC and the SMEs' efficiency; for example, Hermano and Martin-Cruz (2016) identified the dynamic capabilities of the top management as a mediator between the TMC and the firm's efficiency. Similarly, Huynh, Gudergan and Wilden (2018) also claimed that top management influences the dynamic capabilities of a firm which ultimately affects the firm's performance. They further argue that to achieve a highly sustainable competitive position, a firm needs to have enough resources and capabilities and conclude that to gain a competitive advantage over the competitors it is inevitable to lead others in acquiring the useful and requisite resources (Camisón et al., 2016). Many firms rely on the knowledge and competencies of their managers because competent managers can acquire and seize a more favorable position in resource acquisition and which in turn enhances the high productivity and efficiency of firms (Bharadwaj et al., 2015). Management capabilities are helpful to reduce spurious costs that are aligned with various activities and help firms in the creation of new opportunities that are essential for business profit and success (Gillis et al., 2018; Koryak et al., 2015). To acquire valuable resources, organizations need skilled and active HR managers who 
in turn help in the improvement of firm performance (Antila \& Kakkonen, 2008). Managers' dynamic capabilities serve as a catalyst for mobilization of the resources in an efficient way to provide maximum outputs (Huy \& Zott, 2019).

TMC such as networking and interaction do not directly influence firm performance but initially, it (e.g., capabilities) helps in bringing resources from the external environment and then uses these resources to enhance their profitability (Jiang et al., 2018). This notion is further enriched by Ying et al. (2019) who scrutinized that resource acquisition is the significant mediator between top managers' intangible capabilities and sustainable competitive position in SMEs. Similarly, it is also argued that competent marketing managers help firms to build easy ways to access various resources that can configure business growth and sustainable performance. Managers are deemed as the success factors which enable a firm to achieve its target goal, sustainable position and high profitability by acquiring valuable resources (Richey, Kiessling, Tokman \& Dalela, 2008). Therefore, based on these assertions we also hypothesize the same mediating relationship and states the next hypothesis as:

$\mathrm{H}_{4}$ : Top management capabilities increases the chances of resources acquisition, which resultantly increases the efficiency of the SMEs of Pakistan.

Conceptual Model is shown in figure 1.

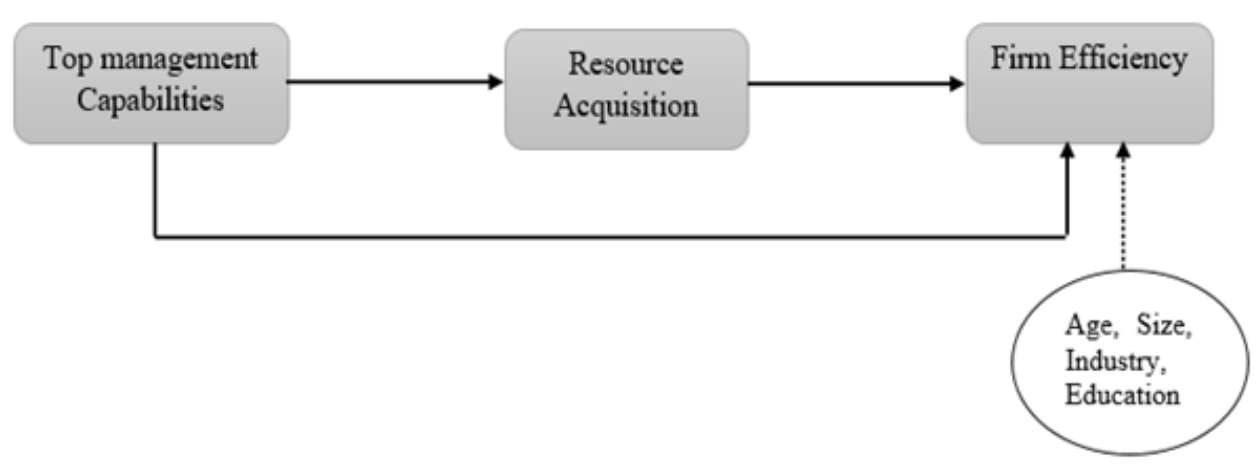

Figure 1: Conceptual Model

\section{Methodology}

\subsection{Research design, sample and population}

To achieve the objectives, this study is attributed as a quantitative study, which is based on a survey to collect cross-sectional data of the top management of SMEs in Pakistan. We collected data from 311 SMEs operating in the three major cities of 
Pakistan; Islamabad, Peshawar and Lahore. We selected SMEs from these three cities as most of them have their head offices in these cities (Anwar, 2018). We obtained registered firms lists from Islamabad Chamber of Commerce and Industries (ICCI), Sarhad Chamber of Commerce and Industries (SCCI), and Lahore Chamber of Commerce and Industries (LCCI) which have around 4000, 3900 and 5980 registered firms, respectively; making a total population of 13880 SMEs. Based on the probability-based sampling formula, a sample size above 300 is a good representative (Krejcie \& Morgan, 1970). Additionally, Osborne, Costello and Kellow (2008) suggested a ratio of 10 to 15 respondents to one item as an acceptable criterion for deciding the sample size to get unbiased estimates. Following this criterion (18 items x $15=270$ responses), we distributed 700 questionnaires among the firms, randomly selected from the list of the firms obtained from the relevant chamber's registered firms' lists, to get a response of at least 270 . We requested the owners and top managers of the randomly selected firms to fill the survey as they are more aware of their strategic planning and performance. This research followed a hard copy approach for data collection because an email survey gives a lower response rate in Pakistan (Anwar, 2018). Another reason for choosing this approach is to approach directly the respondents in their working stations and to get their responses as either they have little time to fill the online surveys or do not bother to respond to emails. We received 311 usable questionnaires from the selected SMEs with a response rate of $44.43 \%$. The descriptive profiles of the firms participated in this study are shown in Table-3.

Table 3: Description of the SMEs participated in the Research

\begin{tabular}{|c|c|c|}
\hline Description & No. of firms & Percentage \\
\hline Size of the firms & & 24.1 \\
\hline $20-50$ employees & 75 & 19.9 \\
\hline $51-100$ employees & 62 & 17.7 \\
\hline $101-150$ employees & 55 & 18.3 \\
\hline $151-200$ employees & 57 & 19.9 \\
\hline 201 to 250 employees & 62 & 39.9 \\
\hline Age of the firms & & 32.8 \\
\hline 10 years and less & 124 & 27.3 \\
\hline $11-20$ years & 102 & \\
\hline 21 and above years & 85 & 36.0 \\
\hline Nature of Industry & & 39.9 \\
\hline Manufacturing & 112 & \\
\hline Trading & 124 & \\
\hline
\end{tabular}




\begin{tabular}{|c|c|c|}
\hline Services & 75 & 24.1 \\
\hline Education of Owners/Managers & & \\
\hline Intermediate and less & 52 & 16.7 \\
\hline Bachelor & 114 & 36.7 \\
\hline Master & 97 & 31.2 \\
\hline MS / MPhil & 46 & 14.8 \\
\hline PhD & 2 & 0.60 \\
\hline Total & 311 & 100 \\
\hline
\end{tabular}

\subsection{Measures}

Top Management Capabilities: TMC are measured as multi-dimensional concepts and encompass a variety of management capabilities. To gain comprehensive insights, we modified the items used in the prior studies (e.g. Nadolska \& Barkema, 2014; Ruiz-Jiménez \& Fuentes-Fuentes, 2016) and merged the total six items to measure TMC. The previous study has reported reliability statistics of 0.90 for the construct of the TMC (e.g., Ruiz-Jiménez \& Fuentes-Fuentes, 2016).

Resource Acquisition: Firms with tangible and intangible resources that facilitate a competitive advantage. We used measures used by Campbell and Park, (2016), Ying et al. (2019) and Lee, Tuselmann, Jayawarna and Rouse (2018) in the SMEs perspective where six items were used (slightly modified) for resource acquisition (tangible $\&$ intangible resources). The previous study established its reliability as Cronbach's Alpha for this measure was 0.93 (Ying et al., 2019).

Firm Efficiency: In the case of large firms, data are available and various proxies are used to measure efficiency. However, in SMEs, different self-reported approach has been used to measure performance, productivity and competitiveness. We adopted the measures used in the prior study (e.g. Martin \& Javalgi, 2016) and modified as per the study's requirements. Owners/managers were asked, "we have significantly improved our return on investment, return on assets and market share etc. using the least resources since the last three years as compared to our major competitors". Cronbach's Alpha was reported 0.87 by Martin and Javalgi, (2016), hence a reliable instrument for measuring the Firm's Efficiency.

All the variables are measured with 5 points Likert scales (e.g., strongly disagree -1 , disagree -2 , neutral/average -3 , agree $-4 \&$ strongly agree -5$)$.

\subsection{Control Variables}

To control for the effects of the demographics of the SMEs, and to reduce spurious 
results, we controlled for the age of firms, size of firms, nature of industry and education of top management. Since the nature of the industry is a categorical variable, we performed a separate group difference analysis in AMOS. We did not find any significant differences between the manufacturing, trading and service group. Hence, we dropped the nature of the industry to be controlled. Size has insignificant while age and education show a significant influence on firm efficiency.

\section{Data Analysis and Results}

\subsection{Exploratory factor analysis}

Since the items are slightly modified therefore we conducted Exploratory Factor Analysis (EFA) to validate the scales. We executed EFA on the 18 items using Varimax Rotation with Kaiser Normalization method. The results of the EFA are provided in Table -4 . The results of the sample adequacy indicate that the sample is enough to execute EFA as Kaiser-Meyer-Olkin (KMO) value is greater than 0.70 (Barrett \& Morgan, 2005). Communalities values were acceptable for each items (e.g., > 0.50). Further results of EFA confirmed the convergent and construct validity as each item was significantly loaded on its respective factor with satisfactory value as shown in Table -5 .

Table 4: KMO and Bartlett's Test

\begin{tabular}{|c|c|c|}
\hline \multicolumn{2}{|c|}{ Kaiser-Meyer-Olkin Measure of Sampling Adequacy. } & 0.877 \\
\hline Bartlett's Test of Sphericity & Approx. Chi-Square & 3794.477 \\
\hline & Df & 153 \\
\hline & Sig. & 0.000 \\
\hline
\end{tabular}

\subsection{Descriptive statistics}

Descriptive statistics, provided in Table -6 , shows that the average mean values of the items are around 3 and the standard deviation is about 0.50 . The data are normal as none of the items has skewness and kurtosis values greater than $-/+2$ which confirmed the normality of the data (George \& Mallery, 2010).

\subsection{Confirmatory factor analysis}

We also performed Confirmatory Factor Analysis (CFA) to examine the items' standardized loading, validity and reliability, followed by estimation of the structural model through AMOS to test the hypotheses of the study. The estimation of the measurement model (see Figure 2) is conducted through the CFA. First, we ensured the fitness of the model (see Table 9) such as CMIN/DF that is less than 3 (Hair, 
Table 5: Factor Loadings: Exploratory Factor Analysis

\begin{tabular}{|c|c|c|c|}
\hline Items & 1 & 2 & 3 \\
\hline tmc1 & 0.787 & 0.053 & 0.000 \\
\hline tmc2 & 0.748 & 0.049 & 0.170 \\
\hline tmc3 & 0.799 & 0.053 & 0.037 \\
\hline tmc4 & 0.779 & 0.112 & 0.184 \\
\hline tmc5 & 0.807 & 0.019 & 0.134 \\
\hline tmc6 & 0.769 & 0.094 & 0.027 \\
\hline ra1 & 0.019 & 0.865 & 0.258 \\
\hline ra2 & 0.041 & 0.910 & 0.186 \\
\hline ra3 & 0.077 & 0.876 & 0.113 \\
\hline ra4 & 0.036 & 0.803 & 0.306 \\
\hline ra5 & 0.161 & 0.833 & 0.127 \\
\hline ra6 & 0.100 & 0.808 & 0.241 \\
\hline ef1 & 0.072 & 0.161 & 0.746 \\
\hline ef2 & 0.096 & 0.146 & 0.781 \\
\hline ef3 & 0.131 & 0.133 & 0.833 \\
\hline ef4 & 0.032 & 0.258 & 0.735 \\
\hline ef5 & 0.157 & 0.164 & 0.854 \\
\hline ef6 & 0.079 & 0.241 & 0.610 \\
\hline mef & & & \\
\hline
\end{tabular}

Extraction Method: Principal Component Analysis. a. 3 components extracted.

$\mathrm{ra}=$ resource acquisition, fe=firm efficiency, $\mathrm{tmc}=$ top management capabilities

Table 6: Descriptive Statistics

\begin{tabular}{|c|c|c|c|c|c|c|}
\hline Items & Minimum & Maximum & Mean & S.D & Skewness & Kurtosis \\
\hline ra1 & 2 & 5 & 3.68 & 0.571 & -0.291 & -0.072 \\
\hline ra2 & 2 & 5 & 3.71 & 0.573 & -0.619 & 0.527 \\
\hline ra3 & 2 & 5 & 3.71 & 0.569 & -0.442 & 0.226 \\
\hline ra4 & 2 & 5 & 3.72 & 0.557 & -0.443 & 0.246 \\
\hline ra5 & 2 & 5 & 3.70 & 0.566 & -0.461 & 0.201 \\
\hline ra6 & 2 & 5 & 3.75 & 0.542 & -0.585 & 0.542 \\
\hline tmc1 & 2 & 5 & 3.70 & 0.554 & -0.559 & 0.264 \\
\hline tmc2 & 2 & 5 & 3.66 & 0.532 & -0.599 & -0.221 \\
\hline tmc3 & 2 & 5 & 3.69 & 0.528 & -0.682 & 0.093 \\
\hline
\end{tabular}




\begin{tabular}{|c|c|c|c|c|c|c|}
\hline tmc4 & 2 & 5 & 3.66 & 0.568 & -0.582 & 0.125 \\
\hline tmc5 & 2 & 5 & 3.72 & 0.539 & -0.591 & 0.356 \\
\hline tmc6 & 2 & 5 & 3.65 & 0.553 & -0.498 & -0.143 \\
\hline ef1 & 2 & 5 & 3.78 & 0.486 & -1.155 & 1.618 \\
\hline ef2 & 2 & 5 & 3.80 & 0.505 & -0.609 & 0.884 \\
\hline ef3 & 2 & 5 & 3.78 & 0.513 & -0.990 & 1.495 \\
\hline ef4 & 3 & 5 & 3.84 & 0.457 & -0.608 & 0.802 \\
\hline ef5 & 2 & 5 & 3.80 & 0.521 & -1.037 & 1.919 \\
\hline ef6 & 2 & 5 & 3.81 & 0.461 & -0.645 & 0.448 \\
\hline
\end{tabular}

Note: $\mathrm{Ra}=$ resource acquisition, $\mathrm{fe}=$ firm efficiency, $\mathrm{tmc}=$ top management capabilities

Anderson, Babin \& Black, 2010; Hu \& Bentler, 1999). The GFI, AGFI, CFI, NFI and TLI values are higher than 0.90 that shows the acceptable model's fit (Hair et al., 2010; Hu \& Bentler, 1999). RMR and RMSEA are also in the acceptable ranges e.g. less than 0.08 (Hair et al., 2010; Hu \& Bentler, 1999). All the items have adequate standardized factor loading (above $0.70, \mathrm{p}<0.001$ ) on their relevant factors, as shown in Table - 7. Additionally, the convergent validity of the factors is also ensured as shown in Table -8 , which are in acceptable values (above the threshold value of 0.50 ) (Hair et al., 2010; Hu \& Bentler, 1999). Discriminant validity (see Table - 8) is also ensured as the values are above the threshold value of 0.70 (Hair et al., 2010; Hu \& Bentler, 1999). Composite reliability (see Table -8 ) of all the factors is in acceptable ranges i.e., > 0.70 (Hair et al., 2010; Hu \& Bentler, 1999). Thus all the criteria of the measurement model have achieved, therefore the reliability and validity of the instruments are established.

Table 7: Factor Loadings: Confirmatory Factor Analysis

\begin{tabular}{|c|c|c|}
\hline \multicolumn{2}{|c|}{ Top Management Capabilities } & Estimate \\
\hline tmc6 & $\begin{array}{c}\text { The firm's managers achieve better total control of the firm's general } \\
\text { performance. }\end{array}$ & 0.697 \\
\hline tmc5 & The firm's managers perceive new opportunities and potential threats. & 0.768 \\
\hline tmc4 & $\begin{array}{c}\text { The firm's managers develop a system of strategic plans throughout the } \\
\text { organization that is effective for the organization's general development. }\end{array}$ & 0.798 \\
\hline tmc3 & $\begin{array}{c}\text { The use of management by objectives has increased in the firm. } \\
\text { The extensive, effective use of quantitative techniques in decision mak- } \\
\text { ing has increased. }\end{array}$ & 0.770 \\
\hline
\end{tabular}




\begin{tabular}{|c|c|c|}
\hline tmc1 & $\begin{array}{c}\text { The firm's managers resolve conflicting opinions, improve coordination } \\
\text { and effective collaboration between key executives, generate enthusiasm, } \\
\text { and motivate the management unit sufficiently to achieve improved } \\
\text { performance. }\end{array}$ & 0.739 \\
\hline & Resources Acquisition & \\
\hline ra6 & Financial support & 0.797 \\
\hline ra5 & Business strategy advise & 0.756 \\
\hline ra4 & Social capital & 0.852 \\
\hline ra3 & Physical resources (e.g. technologies, equipment etc.) & 0.809 \\
\hline $\mathrm{ra} 2$ & Corporate social responsibility & 0.944 \\
\hline \multirow[t]{2}{*}{ ra1 } & Industry information & 0.899 \\
\hline & Firm Efficiency & \\
\hline ef6 & Reaching the venture financial goals & 0.554 \\
\hline ef5 & The venture margin & 0.905 \\
\hline ef4 & Market growth & 0.664 \\
\hline ef3 & Return on Assets (ROA) & 0.847 \\
\hline ef2 & Return on sales (ROS) & 0.716 \\
\hline ef1 & Return on investment (ROI) & 0.705 \\
\hline
\end{tabular}

Note: $\mathrm{Ra}=$ resource acquisition, $\mathrm{fe}=$ firm efficiency, $\mathrm{tmc}=$ top management capabilities

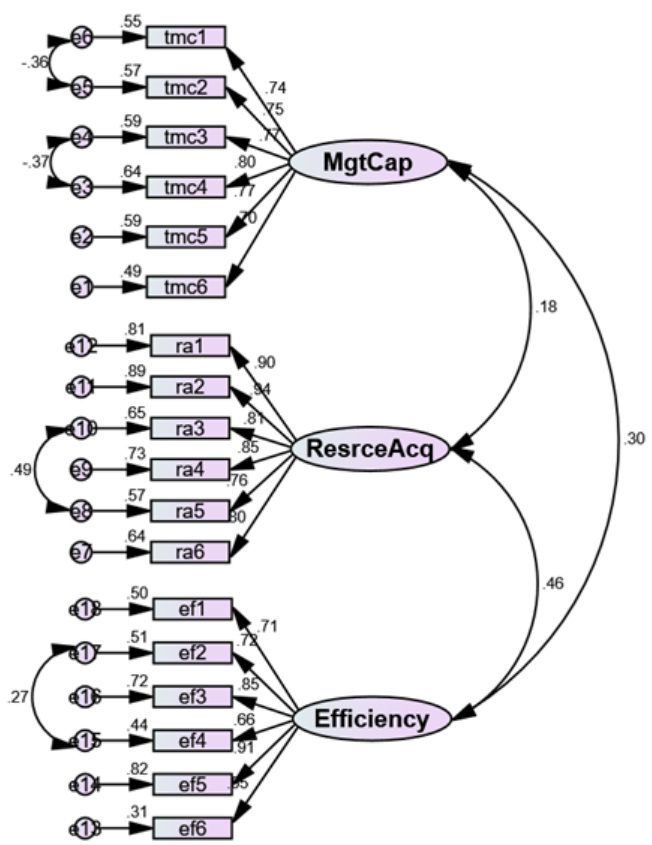

Figure 2: Measurement Model 


\subsection{Common Method Variance (CMV)}

We relied on cross-sectional data which is prone to the problems of common method bias. To examine the prevalence of the CMV, we performed Harman's one-factor test in SPSS using Principle Component Analysis (PCA). The results indicated three factors that have eigenvalues greater than 1 of which the first factor explained only $36.92 \%$ variance which is less than 50\% (Podsakoff \& Organ, 1986), therefore, the common method is not a problem in this study and can interpret the results of this study confidently being unbiased.

\subsection{Correlation}

We executed the Pearson correlation in SPSS to check the relationships between the variables of the study. The correlation matrix is provided in Table 8, which shows that TMC have significant positive association with both the firm's efficiency $(r=$ $0.321, p<0.01)$ and resources acquisition $(r=0.189, p<0.01)$. In addition, there is a significant and positive relationship between resource acquisition and the firm's efficiency $(r=0.489, \mathrm{p}<0.01)$.

Table 8: Correlation Coefficients

\begin{tabular}{|c|c|c|c|c|c|c|c|c|c|}
\hline Factors & AVE & $\sqrt{ }$ AVE & C.R & Size & Age & $\begin{array}{c}\text { educa- } \\
\text { tion }\end{array}$ & TMC & RA & $\begin{array}{c}\text { Firm Ef- } \\
\text { ficiency }\end{array}$ \\
\hline Size & - & - & - & 1 & & & & & \\
\hline Age & - & - & - & 0.068 & 1 & & & & \\
\hline Education & - & - & - & -0.034 & $0.165^{* *}$ & 1 & & & \\
\hline TMC & 0.57 & 0.75 & 0.89 & -0.015 & $0.157^{* *}$ & $0.149^{* *}$ & 1 & & \\
\hline RA & 0.71 & 0.85 & 0.94 & 0.072 & $0.229^{* *}$ & 0.099 & $0.189^{* *}$ & 1 & \\
\hline $\begin{array}{c}\text { Firm Effi- } \\
\text { ciency }\end{array}$ & 0.55 & 0.74 & 0.88 & 0.068 & $0.442^{* *}$ & $0.364^{* *}$ & $0.321^{* *}$ & $0.489^{* *}$ & 1 \\
\hline
\end{tabular}

${ }^{* *}$. Correlation is significant at the 0.01 level (2-tailed). AVE=average variance extracted, $C . R=c o m-$ posite reliability, $\mathrm{TMC}=$ Top Management Capabilities, $\mathrm{RA}=$ resource acquisition

\subsection{Structural model estimation}

Hypotheses of the study were tested through the structural model using AMOS. To gain valid insights, we executed a separate model for each relationship. The estimation and their interpretations are provided in the relevant sections.

\subsubsection{Structural model 1}

In this structural model (see Figure 3), the influence of TMC on firms efficiency 
was examined. First, we ensured the fitness of the model (see Table - 9) in terms of CMIN/DF, which is less than 3 (Hair et al., 2010; Hu \& Bentler, 1999). GFI, AGFI, CFI, NFI and TLI values are greater than 0.90 shows acceptable model fits as per the recommendations of the prior studies (Hair et al., 2010; Hu \& Bentler, 1999). RMR and RMSEA are also in the acceptable ranges (i.e., less than the threshold values of 0.09) as recommended by Hair et al., (2010) and Hu and Bentler, (1999). The structural model estimation results, as shown in Table - 10, show that TMC have a significant and positive influence on efficiency $(\beta=0.127, p<0.05)$ which supported the $\mathrm{H}_{1}$. However, for the control variables, the only size has an insignificant while education and age have a significant influence on the firm's efficiency. $\mathrm{R}^{2}$ shows that a 30\% change in efficiency is explained by TMC while controlling for the educational background of top managers, size and age of firms as control variables.

\subsubsection{Structural model 2}

In the second structural model (see Figure 4), the influence of TMC on resource acquisition was examined. The goodness of fit of the model was assessed (see Table 9), which shows a good fitness of the model as the values of CMIN/DF GFI, AGFI, CFI, NFI, TLI, RMR and RMSEA are in the acceptable ranges (Hair et al., 2010; $\mathrm{Hu} \&$ Bentler, 1999). The results (see Table 10) show that TMC have a significant influence on resource acquisition $(\beta=0.157, \mathrm{p}<0.05)$ which supported hypothesis $\mathrm{H}_{2}$. $\mathrm{R}^{2}$ indicates that only a $6 \%$ variation in resource acquisition is explained by TMC after controlling for the control variables; education of the top managers, size and age of firms.

\subsubsection{Structural model 3}

The effect of resource acquisition on firms efficiency was examined through structural model 3 (see Figure 5). The results showed that there is a satisfactory model fit (see Table - 9) as indicated by the values of CMIN/DF, GFI, AGFI, TLI, NFI, CFI, RMR and RMSEA as suggested by Hair et al., (2010). The results (see Table - 10) indicate that resource acquisition has a significant and positive effect on the firm's efficiency $(\beta=0.280$, $p<0.05)$ thereby supports hypothesis $H_{3} . R^{2}$ shows that a $37 \%$ change in efficiency is explained by the resource acquisition in the firm's efficiency after controlling for the top manager's education level, the age and size of the firms.

\subsubsection{Structural model 4}

For testing the hypotheses of the research, we applied the structural model in AMOS (see Figure 6). The model fits (see Table 9) were ensured where CMIN/DF is less than 3 (Hair et al., 2010; Hu \& Bentler, 1999). GFI, AGFI, CFI, NFI and TLI values are greater than 0.90 show acceptable model fits as per the recommendation 


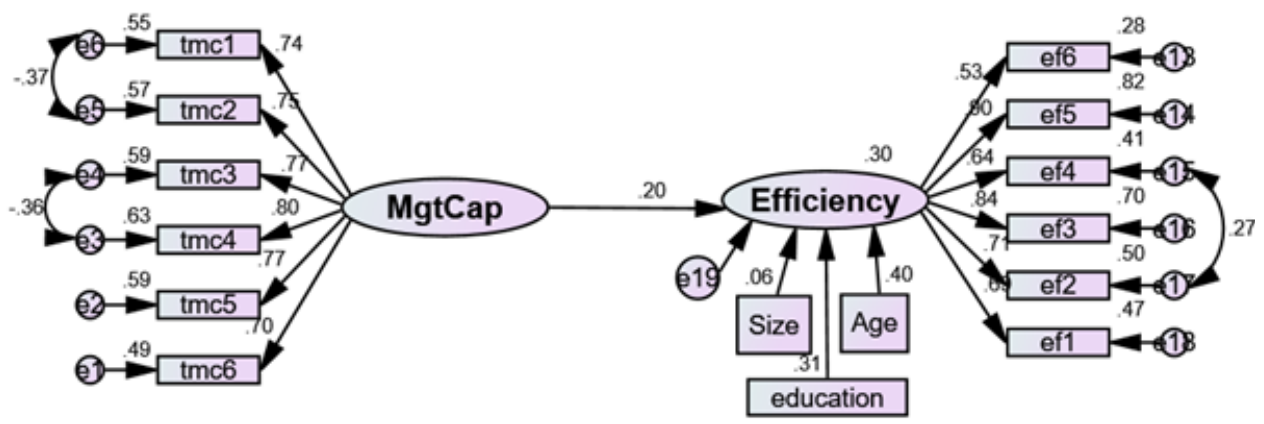

Figure 3: Structural Model 1

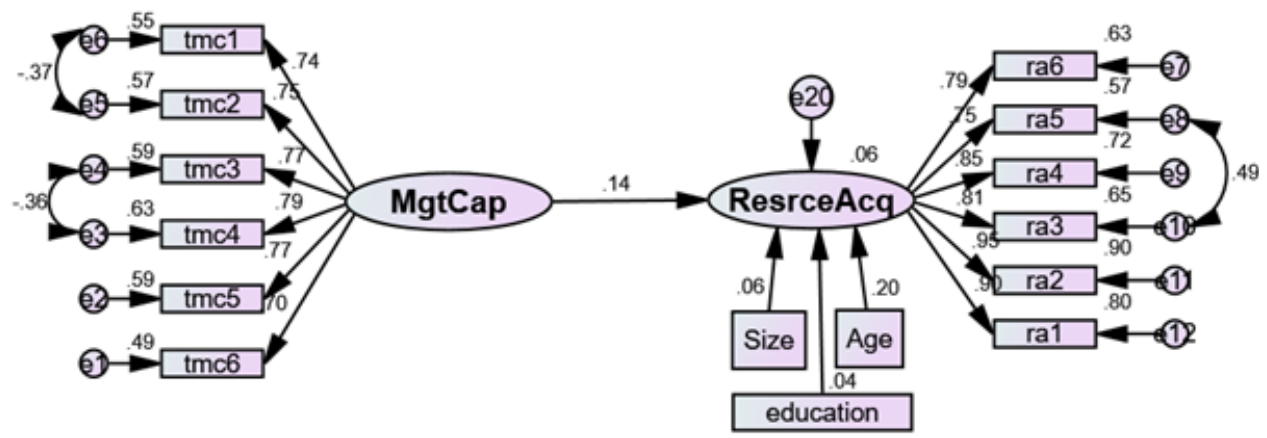

Figure 4: Structural Model 2

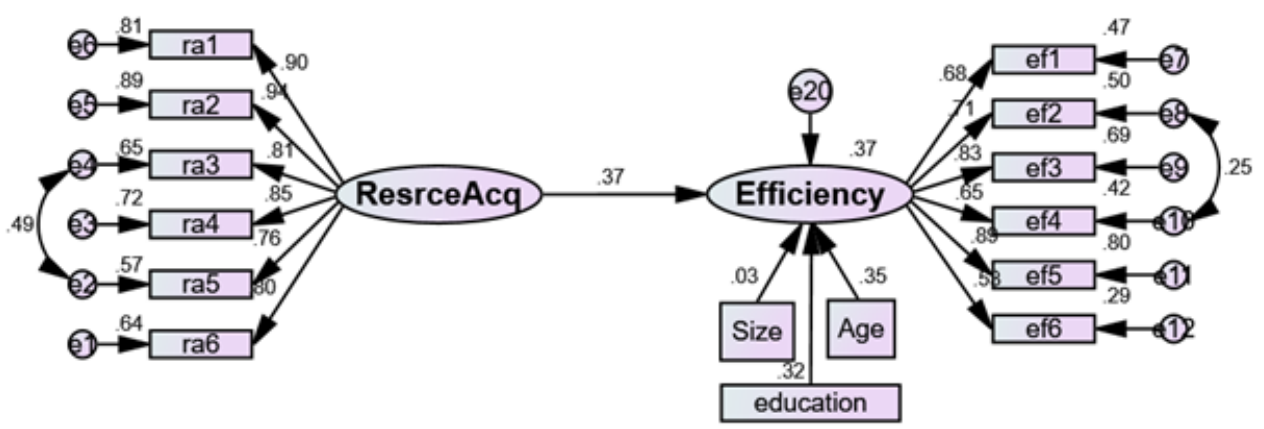

Figure 5: Structural Model 3

of the prior studies (Hair et al., 2010; Hu \& Bentler, 1999). RMR and RMSEA values are lower than 0.08 are accepted (Hair et al., 2010; Hu \& Bentler, 1999) as shown in table 9.

The results show (see Table 11) that the indirect influence of TMC on firm efficiency is significant $(\beta=0.062, p<0.05)$ while the direct influence of TMC on efficiency remained significant that partially supported $\mathrm{H} 4$ of the study. The control variables; education and age of firms are significant while size insignificantly influenced firm 
cy also remains significant $(\beta=0.1561, \mathrm{p}<0.01)$. Whereas, the total linear effect of TMC on firm efficiency was statistically significant $(\beta=0.2115, p<0.01)$. Moreover the

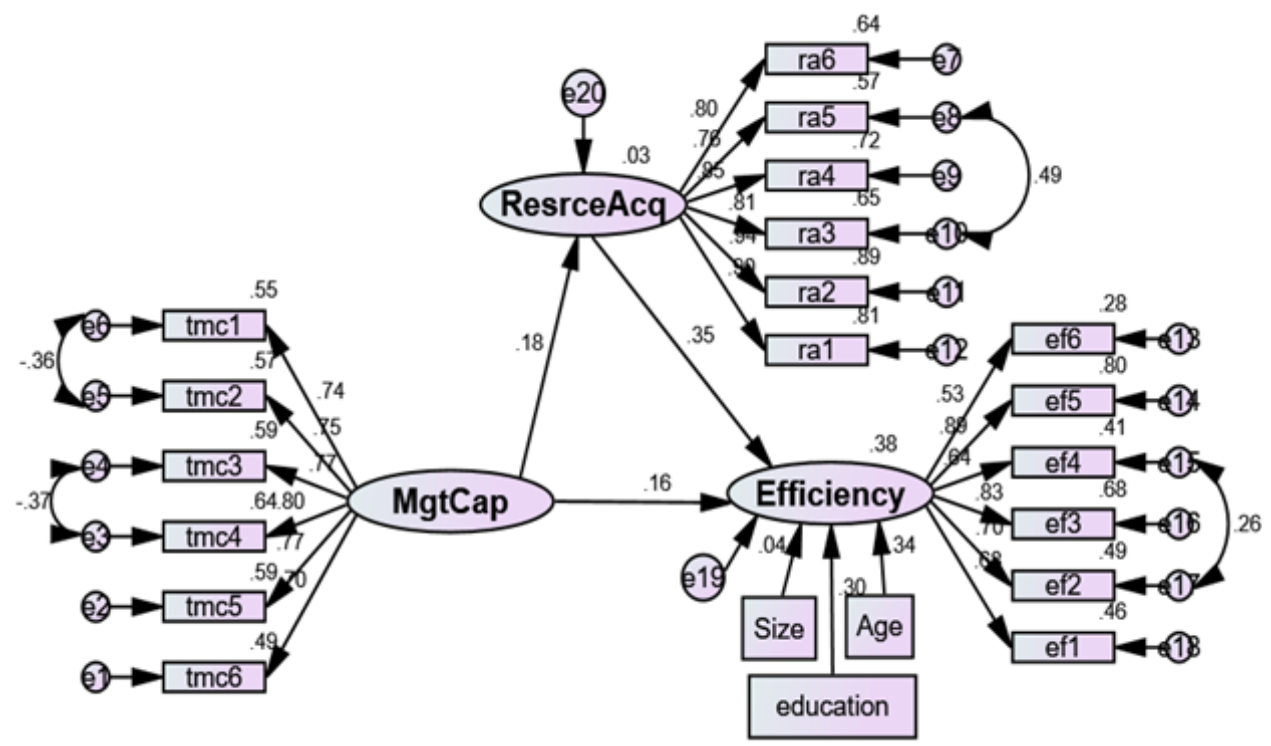

Figure 6: Structural Model 4

Table 9: Goodness of Fit Indices

\begin{tabular}{|c|c|c|c|c|c|c|c|c|}
\hline Model & CMIN/DF & RMR & RMSEA & GFI & AGFI & TLI & CFI & NFI \\
\hline $\begin{array}{c}\text { Measurement } \\
\text { Model }\end{array}$ & 2.413 & 0.015 & 0.068 & 0.90 & 0.87 & 0.94 & 0.95 & 0.92 \\
\hline $\begin{array}{c}\text { Structural } \\
\text { Model 1 }\end{array}$ & 1.848 & 0.030 & 0.052 & 0.93 & 0.91 & 0.96 & 0.96 & 0.92 \\
\hline $\begin{array}{c}\text { Structural } \\
\text { Model 2 }\end{array}$ & 2.316 & 0.028 & 0.065 & 0.92 & 0.89 & 0.95 & 0.96 & 0.93 \\
\hline $\begin{array}{c}\text { Structural } \\
\text { Model 3 }\end{array}$ & 2.849 & 0.037 & 0.077 & 0.91 & 0.87 & 0.93 & 0.94 & 0.92 \\
\hline $\begin{array}{c}\text { Structural } \\
\text { Model 4 }\end{array}$ & 2.248 & 0.032 & 0.063 & 0.89 & 0.86 & 0.96 & 0.94 & 0.90 \\
\hline
\end{tabular}

efficiency. Considering the $\mathrm{R}$ square, figure 3 shows that $38 \%$ variance is explained in firm efficiency by TMC with resource acquisition as a mediator.

\subsection{Robustness test}

To increase the validity of the results, we used PROCESS macros in SPSS as suggested by Hayes and Preacher (2013) to test the mediating effect of resource acquisition 
Table 10: Hypotheses Testing (Direct Relations)

\begin{tabular}{|c|c|c|c|c|c|c|}
\hline \multicolumn{3}{|c|}{ Hypotheses } & Estimate & S.E. & C.R. & $\mathrm{P}$ \\
\hline Firm Efficiency & $<$ & TMC & 0.127 & 0.036 & 3.502 & 0.000 \\
\hline Firm Efficiency & $<-$ & Age & 0.118 & 0.019 & 6.276 & 0.000 \\
\hline Firm Efficiency & $<-$ & Size & 0.010 & 0.009 & 1.165 & 0.244 \\
\hline Firm Efficiency & $<-$ & Education & 0.078 & 0.015 & 5.250 & 0.000 \\
\hline \multicolumn{7}{|c|}{ Structural Model 2} \\
\hline Resource Acquisition & $<-$ & TMC & 0.157 & 0.066 & 2.377 & 0.017 \\
\hline Resource Acquisition & $<$ & Size & 0.019 & 0.016 & 1.146 & 0.252 \\
\hline Resource Acquisition & $<-$ & Age & 0.103 & 0.030 & 3.440 & 0.000 \\
\hline Resource Acquisition & $<$ & Education & 0.018 & 0.025 & 0.735 & 0.462 \\
\hline \multicolumn{7}{|c|}{ Structural Model 3} \\
\hline Firm Efficiency & $<-$ & RA & 0.280 & 0.043 & 6.463 & 0.000 \\
\hline Firm Efficiency & $<$ & Size & 0.008 & 0.011 & 0.693 & 0.488 \\
\hline Firm Efficiency & $<$ & Age & 0.141 & 0.021 & 6.556 & 0.000 \\
\hline Firm Efficiency & $<$ & Education & 0.108 & 0.018 & 6.019 & 0.000 \\
\hline
\end{tabular}

Note: $\mathrm{TMC}=$ Top Management Capabilities, RA=resource acquisition

Table 11: Hypotheses Testing (Mediation)

\begin{tabular}{|c|c|c|c|c|c|c|}
\hline Hypotheses & Direct effect & P & $\begin{array}{c}\text { Indirect } \\
\text { effect }\end{array}$ & P & $\begin{array}{c}\text { Total } \\
\text { Effect }\end{array}$ & P \\
\hline $\begin{array}{c}\text { Firm Efficiency <- TMC } \\
\text { (through resource acquisition) }\end{array}$ & 0.157 & 0.012 & 0.062 & 0.008 & 0.219 & 0.005 \\
\hline Resource acquisition <- TMC & 0.177 & 0.010 & - & - & 0.177 & 0.010 \\
\hline $\begin{array}{c}\text { Firm efficiency <- Resource } \\
\text { acquisition }\end{array}$ & 0.353 & 0.001 & - & - & 0.353 & 0.001 \\
\hline Firm efficiency <mAge & 0.341 & 0.001 & - & - & 0.341 & 0.001 \\
\hline Firm efficiency <--Size & 0.039 & 0.443 & - & - & 0.039 & 0.443 \\
\hline Firm efficiency <mEducation & 0.305 & 0.001 & - & - & 0.305 & 0.001 \\
\hline
\end{tabular}

Note: $\mathrm{TMC}=$ Top Management Capabilities

between TMC and firm efficiency. Hypothesis 4 of this study suggested a mediating role of resource acquisition between TMC and firm efficiency. To substantiate Hypothesis 4 the model number 4 of PROCESS macros was applied with a bootstrap sample set to 2000 at a 95 percent confidence interval. The results reported below showed that the indirect effect of TMC on firm efficiency (via resource acquisition) was significant $(\beta=0.0554, p<0.01)$. While the direct effect of TMC on firm efficien- 
results of the Sobel test (normal distribution theory) $(z=3.156, \mathrm{P}<0.01$ ), approved that the indirect effect is significant so it indicates that partial mediating effect exists. Hence partially accept $\mathrm{H} 4$.

The result of the bootstrapping method at 95\% Confidence interval indicates that the indirect effect is significant $(\beta=0.0554, \mathrm{LLCI}=0.0166, \mathrm{ULCI}=0.1085)$. Hence we conclude with $95 \%$ confidence that resource acquisition partially mediates the relationship between TMC and firm efficiency. The $\mathrm{R}$ square value reported below depicts that TMC explained $29.12 \%$ variation in firm efficiency in the presence of resource acquisition. PROCESS macros results endorsed the results of SEM and confirmed that resource acquisition partially mediates the relation between TMC and firm efficiency.

Effect of top management capabilities on Firm Efficiency

1. Effect of $\mathrm{TMC}(\mathrm{X})$ on $\mathrm{FE}(\mathrm{Y})$..............................(Path c)

a. $F(1,310)=35.4321 ., P<0.001, R^{2}=0.1029$

b. $b=0.2115, t=5.9525, P<0.001$

Effect of top management capabilities on Resource acquisition.

2. Influence of $\mathrm{TMC}(\mathrm{X})$ on $\mathrm{RA}(\mathrm{M})$. (Path a)

a. $\mathrm{F}(1,310)=11.4621, \mathrm{P}<0.001, \mathrm{R}^{2}=0.0358$

b. $b=0.2153, t=3.3856, P<0.001$

Effect of top management capabilities and Resource acquisition on Firm Efficiency

3. Influence of TMC(X) and RA(M) on FE.......(Path $c^{\prime} \&$ b)

a. $F(2,309)=63.8057, P<0.001, R^{2}=0.2912$

b. Influence of $\mathrm{M}(\mathrm{RA})$ on $\mathrm{Y}(\mathrm{FE}) \mathrm{b}=0.2572, \mathrm{t}=9.099, \mathrm{P}<0.01$

c. Influence of $\mathrm{X}(\mathrm{TMC})$ on $\mathrm{Y}(\mathrm{FE}): \mathrm{b}=0.1561, \mathrm{t}=4.852, \mathrm{p}<0.01$

4. Sobel test (Normal theory test)

$z=3.156, P<0.01$,

5. Total effect of TMC(X) on FE(Y)

$b=0.2115, t=5.9525, P<0.001$ 


\section{Direct effect of TMC $(\mathrm{X})$ on $\mathrm{FE}(\mathrm{Y})$}

$\mathrm{b}=0.1561, \mathrm{t}=4.8524, \mathrm{P}<0.001$

7. Indirect effect of $\mathrm{TMC}(\mathrm{X})$ on $\mathrm{FE}(\mathrm{Y})$ through $\mathrm{RA}(\mathrm{M})$

$\mathrm{b}=0.0554, \mathrm{P}<0.001$, BootLLCI $=0.0166$, BootLLCI $=0.1085$

Note: Note: $\mathrm{TMC}=$ Top Management Capabilities, $R A=$ resource acquisition, $\mathrm{FE}=$ firm efficiency

\section{Discussion and Conclusion}

The model of this research was based on empirical evidence collected from the owners/managers of Pakistani SMEs through a structured questionnaire. Though the contribution of the prior research should not be underweighted, but this research has tested the upper echelon and RBV theory in a turbulent environmental setting using empirical evidence. However, prior studies have mainly focused on the qualitative approach and have emphasized on developed economies. For instance, upper echelon theory (e.g. developed by Hambrick \& Mason, 1984) emphasized on the top management role in organizational outcomes and performance. This study confirmed that TMC help in the acquisition of useful, rare and imitable external resources which in turn significantly enhance SMEs' efficiency. In other words, we argue that TMC are essential for acquiring external tangible and intangible resources that are necessary for the firm's productivity. In addition to this, this study also contributes to RBV theory which states the role of unique resources in business success and superior performance (e.g., Barney, 1991). We scrutinized that adequate resources (tangible and intangible) spur SMEs' efficiency. In general, the present research favors the upper echelon theory and RBV theory in the following manner.

We found that TMC significantly enhances the firm's efficiency that supported $\mathrm{H}_{1}$ of the study. In line with Bathula and Singh (2015) who concluded that top management involvement is vital for enhancing high efficiency and success. Similarly, Salehi et al., (2018) also argued that TMC are not only prominent for high profitability but also very crucial for boosting operational activities. Additionally, Zhao, Zha, Hou and Liang (2019) claimed that in emerging economies such as China, the top management team significantly influences operational activities and plays a crucial role in the improvement of firm efficiency. We also confirmed in this research that TMC is a significant predictor of SMEs' efficiency.

We also scrutinized that TMC help in acquiring valuable resources that supported the $\mathrm{H}_{2}$ of the study. Consistent with Kauppila, (2015) who claimed that top managers 
establish different network ties with external bodies to obtain useful resources. Moreover, Helfat and Peteraf, (2015) that all managers are not so intellectual to gain valuable resources, some managers are more competent in acquiring necessary resources. Hence, we confirmed that TMC facilitate firms in obtaining external resources. This research favors the findings of Alcalde-Heras, Iturrioz-Landart and Aragon-Amonarriz (2019) who scrutinized that SMEs should strengthen their managerial network to acquire external useful resources that are essential for growth and effectiveness.

This research endorsed that resource acquisition significantly upsurges firms efficiency that supported $\mathrm{H}_{3}$. In this context, Camisón et al., (2016) argued that a firm with useful and valuable resources is more efficient and competitive as compared to the firms face resources shortage. Moreover, the findings favor Ferreira and Fernandes, (2017) who scrutinized that adequate resources enable firms to build effective strategies that are beneficial for the firm's efficiency. This research favors the notion of Anwar et al., (2018a) who claim that sufficient resources spur firms' productivity while lack of resources leads to failure. Therefore, top managers should focus on requiring external tangible and intangible resources to survive in the long run.

This study scrutinized that resource acquisition partially mediates the relationship between TMC and firms efficiency that supported H4. Unlike Gudergan and Wilden (2018) who pointed out that TMC first influence dynamic capabilities which in turn affect firms outputs. The results partially endorse Bharadwaj et al., (2015) who demonstrated that that top managers struggle to make competitive positions through the acquired resources which in turn spur organization productivity and profitability. Additionally, Camisón et al., (2016) also claimed that top managers use their skills and competencies to manage resources that can configure the operational process.

\subsection{Implications for theory}

This research has come up with a few significant implications for owners, managers and practitioners who build strategies and policies for business success and long-term survival. We argued that firms need to invest in TMC which in turn help in acquiring useful resources. In other words, we recommend adequate investment in TMC-being intangible resources instead spending much money in tangible assets. Because, on one side, SMEs have not sufficient financial resources to invest in tangible resources and on the other side, investment in tangible resources is riskier than investment in intangible assets. Alternatively, TMC can enable firms in access to rare, unique and immutable resources that are necessary for efficiency and longterm growth. In the emerging market like Pakistan, many firms (especially SMEs) are unable to survive in the long run due to a lack of resources and lack of government support. Moreover, many SMEs have not enough resources to boost their operational 
activities. Hence, TMC can provide an excellent opportunity to acquire expensive external resources easily to compete in the market and gain high profit. For high productivity and competitiveness, adequate resources are very crucial in the SME sector. The implications of this research are not limited to the emerging market Pakistan, but it also suggests valuable information for SMEs operating in other developing and developed countries. As pointed out by Anwar et al., (2018b), the failure ratio of ventures is not only high in an emerging market but also in on the peak in stable economies. Lack of resources and capabilities are reported as major reasons across the globe. The findings urge caution, given the challenges associated with sustaining and surviving into competitive markets to achieve desirable outcomes e.g. efficiency through TMC, rather believing in irrelevant and insignificant predictors. When top managers of a firm are not capable of configuring their internal activities and building a broad network with external bodies (e.g. suppliers, customers and government etc.), they may not be able to access external resources. Hence, SMEs need to have capable and competent managers in the top hierarchy and less competent in the bottom or perhaps in the middle. Hence, the findings may be deemed being the priority to facilitate firms in boosting their operational activities to enhance their efficiency. To summarize, we argue that the SME sector should give priority to TMC over other activities to bring up external tangible and intangible resources. Additionally, we also advise the government and responsible authorities to support SMEs financially and non-financially to acquire efficient outputs.

\subsection{Limitations and future research}

Having a simplistic model, this research ascends with a few precious implications but still some constraints are aligned. For instance, we focused on the emerging market Pakistan, instead of considering the neighbor countries (e.g. China) to articulate the results in a better way. We used the role of TMC in resource acquisition and SMEs efficiency rather than considering the role in other tangles. In this research, the ambiguous question either TMC significantly facilitate in acquiring tangible or intangible resources is not answered. Hence, we recommend future studies to explore the role of TMC in tangible, intangible, financial and non-financial resources to provide a clear picture. A recent study of Heyden et al., (2018) claims that management characteristics are very beneficial for innovation which may raise a question "do TMC facilitate in technological and management innovation in a different environmental setting?" to be answered in future research. We focused on the firm's efficiency; future studies can be considered other dimensions of performance such as innovative performance, environmental performance and market performance etc. Evidence from developing and emerging markets (being a comparative study) are also recommended to discover critical potential implications. 
To conclude the results showed that TMC significantly affect resource acquisition and firms efficiency. However, resource acquisition partially mediates the relationship between TMC and SMEs' efficiency. We recommend owners and managers to pay considerable attention to TMC instead of believing blindly in tangible resources.

\section{References}

Adner, R., \& Helfat, C. E. (2003). Corporate effects and dynamic managerial capabilities. Strategic Management Journal, 24(10), 1011-1025. https://doi.org/10.1002/smj.331

Alcalde-Heras, H., Iturrioz-Landart, C., \& Aragon-Amonarriz, C. (2019). SME ambidexterity during economic recessions: The role of managerial external capabilities. Management Decision, 57(1), 2140. https://doi.org/10.1108/MD-03-2016-0170

Antila, E. M., \& Kakkonen, A. (2008). Factors affecting the role of HR managers in international mergers and acquisitions: A multiple case study. Personnel Review, 37(3), 280-299.

Anwar, M. (2018). Business model innovation and SMEs performance-Does competitive advantage mediate? International Journal of Innovation Management, 22(07), 1850057.

Anwar, M., Khan, S. Z., \& Khan, N. U. (2018a). Intellectual capital, entrepreneurial strategy and new ventures performance: Mediating role of competitive advantage. Business and Economic Review, 10(1), 63-93.

Anwar, M., Rehman, A. U., \& Shah, S. Z. A. (2018b). Networking and new venture's performance: Mediating role of competitive advantage. International Journal of Emerging Markets, 13(5), 998-1025.

Anwar, M., Shah, S. Z. A., \& Khan, S. Z. (2018c). The role of personality in SMEs internationalization: Empirical evidence. Review of International Business and Strategy, 28(2), 258-282.

Badrinarayanan, V., Ramachandran, I., \& Madhavaram, S. (2019). Resource orchestration and dynamic managerial capabilities: Focusing on sales managers as effective resource orchestrators. Journal of Personal Selling E Sales Management, 39(1), 23-41.

Barney, J. (1991). Firm resources and sustained competitive advantage. Journal of management, 17(1), 99-120.

Leech, N.L., Barrett, K. C., \& Morgan, G. A. (2005). SPSS for intermediate statistics: Use and interpretation (2nd ed.). Mahwah, NJ: Lawrence Erlbaum Associates Publishers.

Bathula, H., \& Singh, D. (2015). Ownership concentration, board characteristics and firm performance. Management Decision, 53(5), 911-931.

Bharadwaj, S. S., Chauhan, S., \& Raman, A. (2015). Impact of knowledge management capabilities on knowledge management effectiveness in Indian organizations. Vikalpa, 40(4), 421-434.

Camisón, C., PuigđDenia, A., Forés, B., Fabra, M. E., Muñoz, A., \& Muñoz Martínez, C. É. S. A. R. (2016). The importance of internal resources and capabilities and destination resources to 
explain firm competitive position in the Spanish tourism industry. International Journal of Tourism Research, 18(4), 341-356.

Campbell, J. M., \& Park, J. (2016). Internal and external resources of competitive advantage for small business success: Validation across family ownership. International Journal of Entrepreneurship and Small Business, 27(4), 505-524.

Collins, C. J., \& Clark, K. D. (2003). Strategic human resource practices, top management team social networks, and firm performance: The role of human resource practices in creating organizational competitive advantage. Academy of management Journal, 46(6), 740-751.

Dar, M. S., Ahmed, S., \& Raziq, A. (2017). Small and medium-size enterprises in Pakistan: Definition and critical issues. Pakistan Business Review, 19(1), 46-70.

Dezsö, C. L., \& Ross, D. G. (2012). Does female representation in top management improve firm performance? A panel data investigation. Strategic Management Journal, 33(9), 1072-1089.

Díaz-Fernández, M. C., Gonzalez-Rodríguez, M. R., \& Simonetti, B. (2015). Top management team's intellectual capital and firm performance. European Management Journal, 33(5), 322-331.

Du, J., Guariglia, A., \& Newman, A. (2015). Do social capital building strategies influence the financing behavior of Chinese private small and medium-sized enterprises? Entrepreneurship Theory and Practice, 39(3), 601-631.

Eesley, C. E., Hsu, D. H., \& Roberts, E. B. (2014). The contingent effects of top management teams on venture performance: Aligning founding team composition with innovation strategy and commercialization environment. Strategic Management Journal, 35(12), 1798-1817.

Ferreira, J., \& Fernandes, C. (2017). Resources and capabilities' effects on firm performance: What are they? Journal of Knowledge Management, 21(5), 1202-1217.

García-Sánchez, E., García-Morales, V. J., \& Bolívar-Ramos, M. T. (2017). The influence of top management support for ICTs on organisational performance through knowledge acquisition, transfer, and utilisation. Review of Managerial Science, 11(1), 19-51.

George, D., \& Mallery, P. (2010). SPSS for Windows step by step: A simple study guide and reference. Boston, MA: Pearson Education.

Gillis, W. E., Combs, J. G., \& Yin, X. (2018). Franchise management capabilities and franchisor performance under alternative franchise ownership strategies. Journal of Business Venturing, 35(1).

Gul, S., \& Nouman, M. (2009). Innovation in Pakistan? SMES: Making the case for coupling model and looking beyond. Business $\mathcal{E}$ Economic Review, 1(1), 20-25.

Hair, J. F., Anderson, R. E., Babin, B. J., \& Black, W. C. (2010). Multivariate data analysis: A global perspective (7th ed.). Upper Saddle River, NJ: Pearson Education.

Haleblian, J., \& Finkelstein, S. (1993). Top management team size, CEO dominance, and firm perfor- 
mance: The moderating roles of environmental turbulence and discretion. Academy of Management Journal, 36(4), 844-863.

Hambrick, D. C., \& Mason, P. A. (1984). Upper echelons: The organization as a reflection of its top managers. Academy of Management Review, 9(2), 193-206.

Helfat, C. E., \& Martin, J. A. (2015). Dynamic managerial capabilities: Review and assessment of managerial impact on strategic change. Journal of Management, 41(5), 1281-1312.

Helfat, C. E., \& Peteraf, M. A. (2015). Managerial cognitive capabilities and the microfoundations of dynamic capabilities. Strategic Management Journal, 36(6), 831-850.

Hermano, V., \& Martín-Cruz, N. (2016). The role of top management involvement in firms performing projects: A dynamic capabilities approach. Journal of Business Research, 69(9), 3447-3458.

Heyden, M. L., Sidhu, J. S., \& Volberda, H. W. (2018). The conjoint influence of top and middle management characteristics on management innovation. Journal of Management, 44(4), 1505-1529.

Hu, L. T., Bentler, P. M., (1999). Cutoff criteria for fit indexes in covariance structure analysis: Conventional criteria versus new alternatives. Structural Equation Modeling, 6(1), 1-55.

Huy, Q., \& Zott, C. (2019). Exploring the affective underpinnings of dynamic managerial capabilities: How managers' emotion regulation behaviors mobilize resources for their firms. Strategic Management Journal, 40(1), 28-54.

Huynh, K. T., Gudergan, S. P., \& Wilden, R. (2018). The interaction between top management teams and board of directors in dynamic capabilities. Academy of Management Proceedings, 2018(1), 16085.

Jiang, X., Liu, H., Fey, C., \& Jiang, F. (2018). Entrepreneurial orientation, network resource acquisition, and firm performance: A network approach. Journal of Business Research, 87, 46-57.

Kapetaniou, C., \& Lee, S. H. (2018). Geographical proximity and open innovation of SMEs in Cyprus. Small Business Economics, 1-16.

Kauppila, O. P. (2015). Alliance management capability and firm performance: Using resource-based theory to look inside the process black box. Long Range Planning, 48(3), 151-167.

Kim, N., Shin, S., \& Min, S. (2016). Strategic marketing capability: Mobilizing technological resources for new product advantage. Journal of Business Research, 69(12), 5644-5652.

Ko, E. J., \& McKelvie, A. (2018). Signaling for more money: The roles of founders' human capital and investor prominence in resource acquisition across different stages of firm development. Journal of Business Venturing, 33(4), 438-454.

Koryak, O., Mole, K. F., Lockett, A., Hayton, J. C., Ucbasaran, D., \& Hodgkinson, G. P. (2015). Entrepreneurial leadership, capabilities and firm growth. International Small Business Journal, 33(1), 89-105.

Kotabe, M., Jiang, C. X., \& Murray, J. Y. (2017). Examining the complementary effect of political 
networking capability with absorptive capacity on the innovative performance of emerging-market firms. Journal of Management, 43(4), 1131-1156.

Laud, G., Karpen, I. O., Mulye, R., \& Rahman, K. (2015). The role of embeddedness for resource integration: Complementing SD logic research through a social capital perspective. Marketing Theory, 15(4), 509-543.

Lee, R., Tuselmann, H., Jayawarna, D., \& Rouse, J. (2018). Effects of structural, relational and cognitive social capital on resource acquisition: A study of entrepreneurs residing in multiply deprived areas. Entrepreneurship $\mathcal{E}$ Regional Development, 31(5-6), 534-554.

Martin, S. L., \& Javalgi, R. R. G. (2016). Entrepreneurial orientation, marketing capabilities and performance: The moderating role of competitive intensity on Latin American international new ventures. Journal of Business Research, 69(6), 2040-2051.

Nadolska, A., \& Barkema, H. G. (2014). Good learners: How top management teams affect the success and frequency of acquisitions. Strategic Management Journal, 35(10), 1483-1507.

Nielsen, B. B., \& Nielsen, S. (2013). Top management team nationality diversity and firm performance: A multilevel study. Strategic Management Journal, 34(3), 373-382.

Nouman, M., Taj, A., \& Gul, S. (2017). The individual's influence on low-technology innovation: A critical realism based case study on North-West Pakistan's marble sector. Business $\mathcal{E}$ Economic Review, 9(1), 131-155.

Nunnally, J. C., \& Bernstein, I. (1994). Psychometric theory (3rd ed.). USA: McGraw-Hill.

Osborne, J. W., Costello, A. B., \& Kellow, J. T. (2008). Best practices in exploratory factor analysis. In Osborne, J. (ed.), Best practices in quantitative methods. (pp. 86-99). Thousand Oaks, CA: Sage Publications.

Parnell, J. A., Long, Z., \& Lester, D. (2015). Competitive strategy, capabilities and uncertainty in small and medium sized enterprises (SMEs) in China and the United States. Management Decision, 53(2), 402-431.

Pegels, C. C., \& Yang, B. (2000). The impact of managerial characteristics on strategic assets management capabilities. Team Performance Management: An International Journal, 6(5/6), 97-107.

Peterson, R. S., Smith, D. B., Martorana, P. V., \& Owens, P. D. (2003). The impact of chief executive officer personality on top management team dynamics: One mechanism by which leadership affects organizational performance. Journal of Applied Psychology, 88(5), 795.

Podsakoff, P. M. and Organ, D. W. (1986). Self-reports in organizational research: Problems and prospects. Journal of Management, 12(4), 531-544.

Pulka, B. M., Ramli, A. B., \& Bakar, M. S. (2018). Marketing capabilities, resources acquisition capabilities, risk management capabilities, opportunity recognition capabilities and SMEs performance: 
A proposed framework. Asian Journal of Multidisciplinary Studies, 6(1), 12-22.

Richey Jr, R. G., Kiessling, T. S., Tokman, M., \& Dalela, V. (2008). Market growth through mergers and acquisitions: The role of the relationship marketing manager in sustaining performance. Industrial Marketing Management, 37(4), 394-406.

Ruiz-Jiménez, J. M., \& Fuentes-Fuentes, M. D. M., (2016). Management capabilities, innovation, and gender diversity in the top management team: An empirical analysis in technology-based SMEs. BRQ Business Research Quarterly, 19(2), 107-121.

Sahimi, M., Rizal, A. M., Husin, M. M., \& Kamarudin, S. (2017). The role of management capabilities on entrepreneurial orientation and firm growth relationship. Advanced Science Letters, 23(4), 3013-3015.

Salehi, M., DashtBayaz, M. L., \& Moghadam, S. M. (2018). The relationship between management characteristics and firm innovation. International Journal of Productivity and Performance Management, 67(7), 1113-1131.

Sambasivan, M., Abdul, M., \& Yusop, Y. (2009). Impact of personal qualities and management skills of entrepreneurs on venture performance in Malaysia: Opportunity recognition skills as a mediating factor. Technovation, 29(11), 798-805.

Schriber, S., \& Löwstedt, J. (2015). Tangible resources and the development of organizational capabilities. Scandinavian Journal of Management, 31(1), 54-68.

Shah, A., Gul, S., \& Aziz, R. (2011). Problems facing the Hayatabad industrial estate and their implications on policy formulation. Business EE Economic Review, 2(3), 164-174.

Sirmon, D. G., \& Hitt, M. A. (2003). Managing resources: Linking unique resources, management, and wealth creation in family firms. Entrepreneurship theory and practice, 27(4), 339-358.

Smith, N., Smith, V., \& Verner, M. (2006). Do women in top management affect firm performance? A panel study of 2,500 Danish firms. International Journal of Productivity and Performance Management, 55(7), 569-593.

Songling, Y., Ishtiaq, M., Anwar, M., \& Ahmed, H. (2018). The role of government support in sustainable competitive position and firm performance. Sustainability, 10(10), 1-17.

Spithoven, A., \& Teirlinck, P. (2015). Internal capabilities, network resources and appropriation mechanisms as determinants of R\&D outsourcing. Research Policy, 44(3), 711-725.

Tseng, S. M., \& Lee, P. S. (2014). The effect of knowledge management capability and dynamic capability on organizational performance. Journal of Enterprise Information Management, 27(2), 158-179.

Yang, S., Ishtiaq, M., \& Anwar, M. (2018). Enterprise risk management practices and firm performance, the mediating role of competitive advantage and the moderating role of financial literacy. Journal of Risk and Financial Management, 11(3), 1-17.

Ying, Q., Hassan, H., \& Ahmad, H. (2019). The role of a manager's intangible capabilities in resource 
acquisition and sustainable competitive performance. Sustainability, 11(2), 527.

Zhang, Y., Liu, S., Tan, J., Jiang, G., \& Zhu, Q. (2018). Effects of risks on the performance of business process outsourcing projects: The moderating roles of knowledge management capabilities. International Journal of Project Management, 36(4), 627-639.

Zhao, L., Zha, Y., Hou, R., \& Liang, L. (2019). Unobservable effort, objective consistency and the efficiencies of the principal and the top management team. Journal of the Operational Research Society, 70(6), 1011-1026.

Zott, C., \& Huy, Q. N. (2007). How entrepreneurs use symbolic management to acquire resources. Administrative Science Quarterly, 52(1), 70-105. 
